\title{
PERANAN PENGAJAR DI RUMAH PINTAR DALAM MENUMBUHKAN MINAT BACA PENGGUNA
}

\author{
Feby Emani ${ }^{1}$ Yunus Winoto ${ }^{2}$ Nuning Kurniasih ${ }^{3}$ \\ 1,2,3 Program Studi Ilmu Perpustakaan Fikom Unpad \\ febyhabibie@gmail.com ${ }^{1}$, yunus.winoto@unpad.ac.id ${ }^{2}$, nuning.kurniasih@unpad.ac.id ${ }^{3}$
}

\begin{abstract}
The purpose of this study was to determine the "role of teachers in the growing smart home smart home users reading Mekarsari Ciwidey village". The method used in this research is descriptive quantitative method. Techniques of data collection through observation, interviews, and questionnaires on children users Smart House, as well as library research. In this study, researchers analyzed that the characteristics of a good teacher is a smart home: to answer and give you the exact reason of the importance of reading books, being able to explain well about the book being discussed, can share experiences about the positive impact of diligent reading, always actively invited to do read books together, always be friendly, provide information about the importance of reading the book again and again, delivering an important message about reading clearly, using language that is easily understood in explaining the importance of reading books. Based on the research results, the researchers concluded that teachers or communicators in Smart House Program in Rural Mekarsari Ciwidey meets the characteristics of a good teacher smart homes. Teachers in the program the smart home has good credibility in delivering messages and information about the importance of reading to children. And content of the message conveyed by the communicator to get a good response from the respondent, as well as the interest in reading are owned by the Village Mekarsari Ciwidey fall into the category of high. Researchers hope that this study can serve as a model for other social foundation to develop children's interest in reading villages in other areas.
\end{abstract}

Keywords: role, children, interest in reading

\footnotetext{
ABSTRAK - Tujuan dari penelitian ini adalah untuk menentukan "Peranan Pengajar di Rumah Pintar Dalam Menumbuhkan Minat Baca Pengguna di Desa Mekarsari Ciwidey". Metode yang digunakan dalam penelitian ini adalah metode deskriptif kuantitatif. Teknik pengumpulan data melalui observasi, wawancara, dan kuesioner pada pengguna anak-anak Rumah Pintar, serta studi pustaka. Dalam studi ini,
}

peneliti menganalisis bahwa karakteristik guru yang baik adalah rumah pintar: untuk menjawab dan memberikan alasan yang tepat tentang pentingnya membaca buku, mampu menjelaskan dengan baik tentang buku yang sedang dibahas, dapat berbagi pengalaman tentang positif dampak rajin membaca, selalu aktif diundang untuk melakukan buku membaca bersama-sama, selalu ramah, memberikan informasi tentang pentingnya membaca buku lagi dan lagi, memberikan pesan penting tentang membaca dengan jelas, menggunakan bahasa yang mudah dipahami dalam menjelaskan pentingnya membaca buku. Berdasarkan hasil penelitian, para peneliti menyimpulkan bahwa guru atau komunikator di Rumah Pintar Program di Pedesaan Mekarsari Ciwidey memenuhi karakteristik guru yang baik rumah pintar. Guru di program rumah pintar memiliki kredibilitas yang baik dalam menyampaikan pesan dan informasi tentang pentingnya membaca untuk anak-anak. Dan isi dari pesan yang disampaikan oleh komunikator untuk mendapatkan respon yang baik dari responden, serta minat baca yang dimiliki oleh Desa Mekarsari Ciwidey jatuh ke dalam kategori tinggi. Para peneliti berharap bahwa penelitian ini dapat berfungsi sebagai model untuk yayasan sosial lainnya untuk mengembangkan minat anak-anak dalam membaca desa di daerah lain.

Kata kunci: peran, anak-anak, minat baca

\section{PENDAHULUAN}

Sebuah negara yang besar adalah sebuah negara yang memiliki sumber daya yang potensial terutama dalam bidang teknologi dan pengetahuan serta pendidikan. Dengan adanya teknologi dan ilmu pengetahuan yang cukup baik, suatu negara akan mampu meningkatkan kesejahteraan serta kemakmuran masyarakatnya. 
Bila dibandingkan dengan negara lain, Indonesia dapat dikatakan masih menghadapi berbagai persoalan dalam mengembangkan ilmu pengetahuan dan teknologi yang dimiliki, terutama mengenai distribusi pendidikan, yang pada akhirnya akan membawa dampak pada aspek lain seperti ekonomi, kesehatan dan lainnya. Untuk dapat mengatasi persoalan yang seperti ini dibutuhkan suatu keinginan dan kekompakan yang bulat terutama dari kalangan para pelajar yang seharusnya membuka mata mereka dalam menghadapi situasi yang seperti ini.

Salah satu target dalam pembangunan Indonesia adalah mengembangkan pemberdayaan masyarakat. Dalam membangun potensi manusia, anak-anak merupakan masa yang paling potensial dimana terjadinya pembentukan sel-sel otak yang berfungsi meningkatkan kecerdasan. Di Negara Indonesia sebanyak 28juta jiwa anak-anak yang berusia $0-10$ tahun yang baru tersentuh pendidikan hanya $7 \%$ dan sebagian besar tersebar diwilayah pedesaan. Oleh karena itu masih banyak anak-anak di Indonesia yang membutuhkan pendidikan.

Dibandingkan dengan negara-negara berkembang, kemampuan membaca (Reading Literacy) anak-anak di Indonesia masih tergolong rendah, bahkan dalam kawasan ASEAN sekali pun. Dalam International Association for Evaluation of Education (IEA) pada tahun 1992, sebuah studi kemampuan membaca murid-murid sekolah dasar kelas IV pada 30 negara di dunia, member kesimpulan bahwa Indonesia menempati urutan ke 29 setingkat di atas Venezuela yang menempati peringkat terakhir pada urutan ke 30. (http://www.kabarindonesia.com/berita.php?pil= $12 \& d n=20120107122105)$.
Kemajuan ilmu pengetahuan dan teknologi berpengaruh besar terhadap kebutuhan informasi. Hal ini merupakan hal yang pasti, karena orang semakin tinggi pendidikan maka akan semakin banyak informasi yang dibutuhkan. Yayasan Satoe Indonesia merupakan suatu yayasan nonprofit yang didirikan oleh sejumlah mahasiswa SBM-ITB Bandung. Tujuan didirikannya yayasan ini adalah memberikan kontribusi kepada Negara Indonesia dengan cara menyediakan sejumlah fasilitas yang digunakan untuk beberapa program seperti pendidikan, pelatihan, pengembangan institusi, pengembangan bisnis kecil dan menengah.

Solidaritas Istri Kabinet Indonesia Bersatu (SIKIB) bekerja sama dengan Sekolah Bisnis Manajemen Institut Teknologi Bandung turut berperan serta dalam pemberdayaan tersebut melalui Program Rumah Pintar. Hadirnya program Rumah Pintar merupakan salah satu upaya yang dilakukan untuk membantu masyarakat yang sulit dijangkau karena letak geografis dalam memperoleh pendidikan dan informasi terutama di daerah Indonesia. Dalam program rumah pintar terdiri dari pengajar pengajar social yang juga membantu masyarakat yang mengunjungi rumah pintar (http://ml.scribd.com/doc 94940535/LKT-RUMAH-PINTAR).

Program Rumah Pintar merupakan program layanan pendidikan non formal dilakukan melalui penyediaan sarana pembelajaran pada suatu daerah yang pernah didatangi oleh Mobil Pintar atau Motor Pintar sebagai tindak lanjut kemandirian suatu daerah. Dirancang dengan strategi pembelajaran yang penuh makna dan menyenangkan bagi peserta didik khususnya anak usia 4-15 tahun. 
Program ini merupakan perpanjangan dari program Mobil Pintar yang sebelumnya sudah pernah diadakan oleh Yayasan Satoe Indonesia. Adanya program Rumah Pintar ini menurut Presiden Yayasan Satoe Indonesia, ditujukan untuk menumbuhkan minat baca dari para pelajar khususnya pelajar yang berada pada usia Sekolah Dasar, dan Sekolah Lanjutan Tingkat Pertama. Karena berdasarkan hasil observasi, siswa usia SD dan SLTP bisa dianggap masih kurang berminat atau enggan membaca bukupadahal dengan membaca buku, wawasan kita akan bertambah dan berguna untuk masa depan (Kutipan hasil wawancara dengan Fikri Thalib. Penasehat Yayasan Satoe Indonesia. Wawancara dilakukan tanggal 10 Oktober 2012).

Rumah Pintar ini dimulai sejak tahun 2006, dan sampai saat ini sudah lebih dari 5 daerah di Indonesia seperti di Surabaya, DKI Jakarta, Maluku, Bali dan Bandung yang memiliki Rumah Pintar. Peneliti hanya akan mengkaji lebih lanjut mengenai program Rumah Pintar yang berlokasi di Bandung yang merupakan Rumah Pintar pertama yang didirikan.

Mengenai lokasi Rumah Pintar itu sendiri, berada di lokasi Ciwidey, Kabupaten Bandung. Alasan pemilihan daerah ini dikarenakan daerah Ciwidey berdasarkan hasil survey pihak Yayasan Satoe Indonesia adalah daerah yang masih minim bantuan, baik dari Pemerintah Indonesia sendiri maupun dari Pemerintah Luar Indonesia. Beda halnya dengan daerah Lembang atau Subang, yang sebelumnya juga menjadi target pengadaan Rumah Pintar, yang sudah banyak mendapatkan bantuan dari Dalam maupun Luar Negeri, terutama dalam bidang agrikultur atau pertanian.
Daerah Ciwidey juga memiliki jumlah anak tidak bersekolah yang paling besar jika dibandingkan daerah lain di Kabupaten dan Kota Bandung sehingga semakin tepatlah pemilihan Ciwidey sebagai sasaran program Rumah Pintar. Disini anak-anak usia sekolah, baik yang mampu bersekolah maupun yang tidak bersekolah, mendapatkan kesempatan yang sama untuk memperoleh pendidikan, meskipun termasuk pendidikan non-formal. Tapi sesuai dengan tujuan Yayasan Satoe Indonesia yaitu untuk memajukan dan mencerdaskan bangsa, selama anak-anak masih gemar membaca, terutama buku-buku yang berbau pendidikan, maka tidak akan ada ketertinggalan dalam bidang pendidikan (Kutipan hasil wawancara dengan Deni Hartanto. Bagian Pengembangan Program Rumah Pintar).

Program Rumah Pintar inipun lebih menyerupai sebuah tempat seperti perpustakaan besar yang berisi ratusan buku, namun agar lebih menarik perhatian anak-anak, di Rumah Pintar ini juga menambahkan berbagai macam fasilitas pendidikan lainnya seperti Leadership and Entrepreneurship Centre (menga- jarkan tentang kepemimpinan dan cara untuk menjadi pengusaha), Art and Culture Centre (mengajarkan tentang seni dan kebudayaan Indonesia), Environment Centre (mengajarkan tentang lingkungan hidup), dan Religious Study Centre (mengajarkan tentang religi dan Agama). Fasilitas-fasilitas tersebut sengaja ditambahkan di dalam Rumah Pintar, mengingat pada saat implementasi program Mobil Pintar, fasilitasfasilitas seperti itu tidak mungkin disediakan mengingat terbatasnya ruang. 
Sejak dimulainya program Rumah Pintar ini pada tahun 2006, hingga tahun 2008, program ini berjalan dengan baik, hal tersebut terlihat dari semakin bertambahnya jumlah anak usia sekolah yang datang dan mengikuti program ini, namun pada tahun 2009 dan 2010, jumlah anak yang datang ke rumah pintar berkurang sekitar 10-15\%, hal tersebut diperkirakan karena semakin banyaknya anak usia sekolah yang lebih memilih untuk menggunakan internet dalam mencari informasi serta wawasan, dibandingkan membaca buku. Berdasarkan latar belakang dan permasalahan tersebut, maka peneliti tertarik untuk mengetahui dan mengkaji lebih lanjut mengenai peranan Pengajar Rumah Pintar dalam menumbuhkan minat baca pengguna.

\section{TINJAUAN PUSTAKA}

Landasan dari Program Pendidikan Rumah Pintar adalah persuasif yang bertujuan untuk mengubah sikap dalam hal ini dijelaskan melalui minat baca anakanak Desa Ciwidey. Oleh karena itulah penelitian ini menggunakan model persuasi dari Hovland, Janis dan Kelly yang cukup tepat untuk mempelajari dan memahami perubahan perilaku. Hovland, Janis dan Kelly menjelaskan komunikasi persuasif adalah suatu proses dimana seorang individu (komunikator) mentransmisikan stimulus (biasanya verbal) untuk mengubah perilaku orang lain (komunikan) (Tan, 1981:93). Proses dari perubahan sikap adalah serupa dengan proses belajar, dalam mempelajari sikap yang baru, ada tiga variabel penting yang menunjang proses belajar tersebut, yaitu:
a. Perhatian
b.Pengertian
c. Pemahaman

Asumsi dasar dari penelitian ini bahwa seorang komunikator memiliki kemampuan untuk mempengaruhi komunikan melalui stimuli yang memiliki tiga variabel yaitu faktor sumber, faktor pesan, dan faktor audiens menjadi perubahan perilaku. Perubahan perilaku sebagai akibat komunikasi persuasif ini bisa terlihat dari perubahan sikap.

\section{Definisi Pengajar}

Pengajar berasal dari kata ajar yang memiliki arti yaitu suatu petunjuk yang diberikan kepada orang supaya diketahui atau diturut. Sedangkan pengajar adalah orang yang mengajar atau memberikan ajaran. Pengajar juga dapat disebut sebagai guru, pendidik, penyuluh, tutor ataupun pensyarah (sumber: http://www.arti kata.com/arti-357361-pengajar.html) seperti yang dapat dilihat dari gambar di bawah ini.

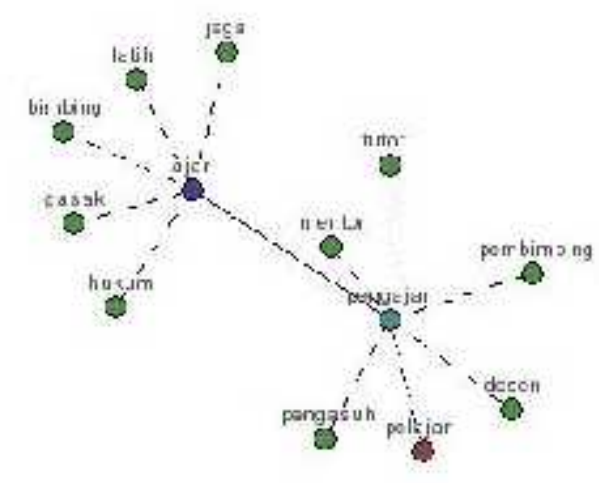

Gambar Diagram Pengertian Kata Pengajar (sumber:http://www.artikata.com/arti-357361-pengajar.html) 
Secara pengertian tradisional guru adalah seorang yang berdiri di depan kelas untuk menyampaikan ilmu pengetahuan (guru professional dan implementasi kurikulum, Syarifuddin Nurdin dan Basyiruddin Usman). Sedangkan menurut Undang-Undang Sistem Pendidikan Nasional, Pendidik adalah tenaga kependidikan yang berkualifikasi sebagai guru, dosen, konselor, pamong belajar, widyaiswara, tutor, instruktur, fasilitator, dan sebutan lain yang sesuai dengan kekhususannya, serta berpartisipasi dalam menyelenggarakn pendidikan (Undang-Undang Sistem Pendidikan Nasional No.20 Tahun 2003 tentang sistem pendidikan nasional). Dengan menelaah dari pengertian guru di atas dapat disimpulkan bahwa seorang guru bukan hanya sekedar pemberi ilmu pengetahuan saja yang berada di depan kelas akan tetapi guru merupakan tenaga professional yang dapat menjadikan murid-muridnya mampu merencanakan, menganalisis dan menyim- pulkan masalah yang dihadapi (Tutik, Daryanto, 2013).

\section{Karakteristik Pengajar yang Baik}

Guru yang efektif memiliki kualitas kemampuan dan sikap yang sanggup memberikan yang terbaik bagi peserta didik dan menyenangkan peserta didik dalam proses belajar mengajarnya. Karakteristik guru efektif adalah sebagai berikut (Tutik, Daryanto, 2013):

- Senantiasa memberikan bantuan dalam kerja sekolah dan pelajar.

- Periang, gembira dan berperawakan menarik.

- Berperikemanusiaan, kasih terhadap peserta didiknya.
- Berminat terhadap dan memahami peserta didiknya.

- Menjadikan suasana pembelajaran menyenangkan.

- Tegas dan pandai mengelola kelasnya.

- Adil, tidak pilih kasih.

- Tidak pemarah, pendendam.

- Berpribadi yang menyenangkan.

Sementara National Commission for Excellence in Teacher Education (USA), mengungkapkan karakteristik guru efektif adalah sebagai berikut (Tutik, Daryanto, 2013)

- Terampil dalam bidangnya.

- Mahir dalam pengajaran.

- Mengikuti perkembangan diri siswa masingmasing.

- Pengalaman tentang psikologi kognitif.

- Mampu dalam mengikuti kemajuan teknologi.

Berdasarkan model karakteristik guru efektif yang dikumukakan beberapa ahli maka berbagai indicator guru efektif yang dikemukakan (Suparlan dalam Tutik, Daryanto, 2013) sebagai berikut :

- Adil dalam tindakan dan perlakuannya.

- Menjaga perawakan dan cara berpakaian.

- Menunjukkan rasa simpati kepada pelajar.

- Mengajar mengikuti kemampuan pelajar.

- Penyayang.

- Bekerja secara tim.

- Memberi semangat pada siswanya.

- Menggunakan berbagai kaidah dan pendekatan dalam pengajarannya.

- Taat kepada etika profesionalismenya.

- Cerdas. 
- Mampu berhubungan secara efektif.

- Tidak garang, pemarah, suka membandel, membesarkan diri, sombong, angkuh dan susah menerima pelajaran orang lain.

- Memiliki sifat kejenakaan dan mau menerima jenaka dari siswa-siswanya.

- Berpengetahuan serta senantiasa berusaha menambah pengetahuannya mengenai perkembangan terbaru terutama dalam bidang teknologi pendidikan.

\section{Peran dan Tugas Pengajar}

Guru memegang peranan yang sangat strategis terutama dalam membentuk watak bangsa serta mengembangkan potensi peserta didik. Kehadiran guru tidak tergantikan oleh unsure yang lain, lebih-lebih dalam masyarakat kita yang multikultural dan multidimensional, dimana peraturan peranan teknologi untuk menggantikan tugas-tugas guru yang sangat minim. Guru memiliki peranan yang sangat penting dalam menentukan keberhasilan pendidikan. Guru yang professional diharapkan menghasilkan lulusan yang berkualitas. Profesionalisme guru sebagai ujung tombak di dalam implementasi kurikulum di kelas yang perlu mendapat perhatian (Depdiknas, 2005).

Dalam proses belajar mengajar, guru mempunyai tugas untuk mendorong, membimbing, dan memberi fasilitas belajar bagi peserta didik untuk mencapai tujuan. Guru mempunyai tanggung jawab untuk melihat segala sesuatu yang terjadi dalam kelas untuk membantu proses perkembangan peserta didik. Penyampaian materi pelajaran hanyalah merupakan salah satu dari berbagai kegiatan dalam belajar sebagai suatu proses yang dinamis dalam segala fase dan proses perkembangan peserta didik. Secara lebih terperinci tugas guru berpusat pada:

- Mendidik dengan titik berat memberikan arah dan motivasi pencapaian tujuan baik jangka pendek maupun jangka panjang

- Memberi fasilitas pencapaian tujuan melalui pengalaman belajar yang memadai. Membantu perkembangan aspek-aspek pribadi seperti sikap, nilai-nilai, dan penyesuaian diri, demikianlah dalam proses belajar mengajar guru tidak terbatas sebagai penyampai ilmu pengetahuan akan tetapi lebih dari itu ia bertanggung jawab akan keseluruhan perkembangan kepribadian perserta didik, ia harus mampu menciptakan proses belajar yang sedemikian rupa sehingga dapat merangsang peserta didik untuk belajar aktif dan dinamis dalam memenuhi kebutuhan dan menciptkan tujuan.

Begitu pentingnya peranan guru dalam keberhasilan peserta didik maka hendaknya guru mampu beradaptasi dengan berbagai perkembangan yang ada dan meningkatkan kompetensinya sebab guru pada saat ini bukan saja sebagai pengajar tetapi juga sebagai pengelola proses belajar mengajar. Sebagai orang yang mengelola proses belajar mengajar tentunya harus mampu meningkatkan kemampuan dalam membuat perencanaan pelajaran, pelaksanaan dan pengelolaan pengajaran yang efektif, penilaian hasil belajar yang objektif, sekaligus memberikan motivasi pada peserta didik terutama ketika peserta didik sedang mengalami kesulitan belajar (Tutik, Daryanto, 2013). 


\section{METODE PENELITIAN}

Metode penelitian yang akan digunakan adalah penelitian deskriptif, yaitu suatu bentuk penelitian yang ditujukan untuk mendeskripsikan fenomena- fenomena yang ada, baik fenomena alamiah maupun fenomena buatan manusia. Fenomena itu bisa berupa bentuk, aktivitas, karakteristik, perubahan, hubungan, kesamaan, dan perbedaan antara fenomena yang satu dengan fenomena lainnya (Rakhmat, 2001). Pene- litian deskriptif merupakan penelitian yang berusaha mendeskripsikan dan menginterpretasikan sesuatu, misalnya kondisi atau hubungan yang ada, pendapat yang berkembang, proses yang sedang berlangsung, akibat atau efek yang terjadi, atau tentang kecende- rungan yang tengah berlangsung

\section{HASIL DAN PEMBAHASAN}

Pada penelitian ini, peneliti menganalisis bahwa karakteristik pengajar rumah pintar yang baik adalah: dapat menjawab dan memberikan alasan yang tepat mengenai pentingnya membaca buku, mampu men- jelaskan dengan baik tentang buku yang sedang dibahas, dapat berbagi pengalaman mengenai dampak positif rajin membaca, selalu aktif mengajak untuk melakukan baca buku bersama, selalu bersikap ramah, memberikan informasi tentang pentingnya membaca buku secara berulang-ulang, menyampaikan pesan tentang penting membaca dengan jelas, menggunakan bahasa yang mudah dipahami dalam menjelaskan pentingnya membaca buku. Berdasarkan hasil penelitian, peneliti menyimpulkan bahwa pengajar atau komunikator dalam Program Rumah Pintar di Desa Mekarsari
Ciwidey telah memenuhi karakteristik pengajar rumah pintar yang baik.

\section{SIMPULAN}

Berdasarkan hasil penelitian pada bab sebelumnya, maka dalam penelitian ini dapat diambil kesimpulan sebagai berikut :

1. Mayoritas responden memberikan penilaian yang baik terhadap komunikator. Maka kesimpulannya adalah komunikator dalam program rumah pintar ini memiliki kredibilitas yang baik dalam menyampaikan berbagai pesan dan informasi khususnya mengenai pentingnya membaca bagi anakanak. Sehingga sudah mulai tertanam kemauan pada anak-anak desa ciwidey untuk giat membaca. Kredibilitas yang dimaksud disini antara lain dapat diindikasikan dari keahlian komunikator dalam menyampaikan materi, kemudian keterpercayaan komunikator dalam arti anak-anak dalam program Rumah Pintar ini mempercayai hal-hal yang disampaikan oleh komunikator, serta daya tarik yang dimiliki komunikator sehingga anak-anak mengerti bahwa buku adalah jendela dunia.

2. Isi pesan yang disampaikan Pengajar Rumah Pintar mudah dimengerti oleh anak-anak desa ciwidey. Hal tersebut terlihat dari mayoritas responden yang enyatakan baik didalam kuesioner yang penulis berikan yaitu terdiri dari struktur pesan serta gaya pesan yang disampaikan oleh komunikator atau pengajar berkaitan dengan pentingnya membaca bagi anak-anak sehingga pada akhirnya akan meningkatkan minat baca anak. 


\section{DAFTAR PUSTAKA}

Adi, I.R. (2003). Pemberdayaan, Pengembangan

Masyarakat dan Intervensi. Komunitas.

Jakarta: Lembaga Penerbit FEUI.

Alwi dan Hasan. (2005). Kamus Besar Bahasa

Indonesia. Jakarta: Pusat Bahasa

Applebaum, R.L., dan Anatol, K.W.E. (1974).

Strategies for Persuasive Communication.

Ohio: A Bell \& Howell, Co

Arikunto, S. (2002). Prosedur penelitian suatu pendekatan praktik. Jakarta: Rineka Cipta

Effendy, Onong Uchjana. (2003). Ilmu

Komunikasi: Teori dan Filsafat Komunikasi, .

Bandung, PT Citra Aditya Bakti

Http://www.artikata.com/arti-357361-pengajar.ht

$\mathrm{ml}$

Rachmawati, Tutik dan Daryanto. (2013).

Penilaian Kinerja Profesi Guru dan Angka

Kreditnya. Yogyakarta. Gava Media.

Rakhmat, Jalaluddin. (2001). Metode Penelitian

Komunikasi. Bandung: Rosdakarya

$$
\text { (2005). Psikologi }
$$

Komunikasi. Bandung : Rosdakarya

R.Roekomy, Drs, (1992). Dasar - Dasar

Persuasi, Penerbit PT. Citra Aditya Bakti,

Bandung

Supardi. (1979). Statistik. Bandung: Fakultas

Tarbiyah IAIN Sunan Gunung Djati.

Tan, Alexis S.. (1981). Masss Communication

Theories and Research. Ohio: Grid

Publishing Inc., Colombus. 